\title{
Geospatial analysis of land cover change and urban sprawl trend in Akure region, Nigeria
}

\begin{abstract}
This study investigates the trend of urban sprawl and land cover change in Akure region between 1985 and 2014 using RS and GIS techniques with the view of examining the direction of the continuous expansion of the city. The pattern of land use change in the study area was determined using aerial imagery overlay function. Imageries obtained for the study were processed and classified, then overlaid to determine the pattern of changes in land use, direction and extent of expansion during the study period. Findings revealed that the city grows sporadically which had unprecedented effects on the pattern of land uses within the city and in the adjoining settlements. There were incompatible conversions in land uses and undue encroachment into green areas in the adjoining communities. In view of this, the study suggests effective zoning strategy to check the indiscriminate nature of urban expansion whose effects on land use are prominent in the study area. Adequate monitoring by the Development Control Department and other stakeholders in urban planning is equally suggested to mitigate the incompatible land use change in the area
\end{abstract}

Keywords: geo-spatial, urban sprawl, land cover, akure region, AIO
Volume 2 Issue I - 2018

\author{
Owoeye JO,' Akinluyi FO² \\ 'Department of Urban and Regional Planning, The Federal \\ University of Technology, Nigeria \\ ${ }^{2}$ Department of Remote Sensing and GIS, The Federal University \\ of Technology, Nigeria
}

\begin{abstract}
Correspondence: Owoeye JO, Department of Urban and Regional Planning, The Federal University of Technology, Nigeria, Tel +2348039179250, Email joowoeye@futa.edu.ng
\end{abstract}

Received: December 22, 2017 | Published: January 12, 2018

\section{Introduction}

Urban sprawl was conceptualized by Glaeser \& $\mathrm{Kahn}^{1}$ as unplanned expansion of urban areas which is characterized by low density physical development and non-existence of basic municipal infrastructure usually beyond urban fringes. Some early urban development researchers like ${ }^{2-4}$ attributed the emergence of sprawl to 'mono-centric city model', which suggests spatial structure of urban areas resulted from the tradeoff between the rent of land and cost of commuting. The low cost-center coupled with relatively low rent at the peripheries of cities in many developing countries facilitates the growth of peri-urban areas. Land use and land cover (LULC) change, on the other hand, is urbanization induced which has led to dramatic changes in land use practices Mirkatouli et al. ${ }^{5}$ Rapid pace of urbanization is believed to be a global problem present in most of the developing countries of the world. Balogun et al. ${ }^{6}$ opined that urban populations in developing countries have grown by $40 \%$ between 1900 and 1975. According to them, the trend will continue adding approximately 2 billion people to the urban population of the presently less-developed nations for the next 30 years. In similar way, Arnfield ${ }^{7}$ observed that the world is becoming increasingly urbanized with $45 \%$ of the population already living in the urban areas in the year 2000. With the projection as at then, half of the world will live in urban areas by 2007. It was also estimated that by the year $2025,60 \%$ of the world's population will live in cities (UNPF, 1999). Akure is not in any way going contrary to this prediction as the population has been more than triple of what it used to be before it became administrative headquarters of the state and local governments.

Generally, land cover is often altered principally by direct human use like agriculture and livestock raising, forest harvesting and management, urban and sub-urban construction and development. Hardly can we find any vegetation that has not been affected or altered by man in the world. ${ }^{8-13}$ In this regard, about 400,000 hectares of vegetation cover are confirmed to be lost annually., ${ }^{6,14}$ Due to anthropogenic activities, the earth surface is being significantly altered by man's presence and several activities on earth. According to Fasal, ${ }^{15}$ land transformation has been asserted to be one of the most important fields of human induced environmental transformation. Environmental protection is facing critical challenges due to several factors like increasing population, depletion of natural resources, environmental pollution, unplanned land use and several others. The aim of this paper, therefore, is to examine changes that have taken place in Akure urban land cover in the past three decades with a view of generating a predictive model for managing the future trend and combating its possible effects.

\section{Review of related literature}

Several researches have shown that unplanned changes of land use and land cover due to urban expansions have become a major problem. ${ }^{6,16,17}$ Most land cover changes occur without a clear and logical planning and without giving attention to their environmental impacts. Major flooding, air pollution in large cities as well as deforestation, urban growth, soil erosion, and desertification, are all consequences of a mismanaged planning and inappropriate projects' execution without considering their environmental impacts. As observed in Nicholson, the rapid land use and land cover changes by the growing population have reduced natural vegetation cover in most countries of the world.

Remote Sensing (RS) and Geographic Information System (GIS) technologies are veritable tools for observing urban growth and its management. The duo provides historical vehicle to monitor, determine and evaluate long term changes in land use due to urbanization process. They have been proved to be effective means for extracting and processing varied resolutions of spatial information for monitoring urban growth. According to Masser, the collection of remotely sensed data facilitates the synoptic analyses of earth in terms of system functioning, burbling, and changes at local, regional and global scales overtime. Such data provides a link between intensive, localized, ecological research and regional, national and international 
conservation and management of biological diversity Wilkie and Finn; Hegazy \& Kaloop. ${ }^{18}$

Land cover changes arising from urbanization, housing development, agriculture, and deforestation are some of the contributing factors to conversion of land cover to urban sprawl in Akure. These changes reflect on the population growth, land consumption rate and local climate. Expansion of Akure has resulted not only in depletion of natural resources, but also in deterioration of the environment due to incompatible changes in land use pattern Oyinloye. ${ }^{19}$ Agriculturally productive land and forestland are being converted to residential and other private and public uses. Balogun et al. ${ }^{6}$ argued that the land use land cover pattern of a region is an outcome of natural and socio-economic factors and their utilization by man in time and space. Hence, the uncontrolled growth of urban development of Akure has adversely affected its ecosystem which may indirectly reflect on weather parameters with eventual local climate modification Akinbode et al., ${ }^{20}$ Balogun.

Akure city functions as the capital of Ondo State and the administrative headquarters of Akure South Local Government Area. Between 1976 when it was created and present time, the city has experienced enormous growth and has developed independently of any spatial urban planning. Its rapid growth became prominently noticed in the last two to three decades. ${ }^{69}$ As urbanized features extended farther from the central areas, lands populated by development are altered in significant ways. From the population figures of past national censuses, the population of Akure increased appreciably from approximately 71,106 in 1963 to 239,124 in 1991 which further increased to 360,268 in 2006 NPC. ${ }^{21}$ Since 1976 when the town became the state capital, there have been remarkable changes in its growth and development. Several developmental projects that brought transformation to the physical landscape of the city are very prominent. For example, $, 17,19$ observed that the construction of Ilesha-Owo expressway opened up the area for further development as it links the city with the northern and eastern parts of the country. Consequently, more developments and establishment of public facilities fascinated to the area are concentrated along this route. To mitigate the negative effects of growth and expansion of the city, there is need to put in place adequate programs and policies that can foster its sustainable development. The essence is to encourage and monitor development in a way that it will not damage the environment for the incoming generations. This can only be achieved by taking appropriate inventory of the available resources and adequately plan for their present and future uses. It is on this premise that this study is set to investigate the influence of urban sprawl on land cover changes in Akure and its surrounding communities.

\section{Materials and methods}

\section{The research locale}

The study centers on Akure city (Figure 1) and its immediate environments. Akure is a notable city in the South-western Nigeria which became the capital of Ondo State on February $3^{\text {rd }}, 1976$. It is located between Latitudes $7^{\circ} 15^{1}$ and $7^{\circ} 17^{1}$ North of the Equator and between Longitudes $5^{\circ} 14^{1}$ and $5^{\circ} 15^{1}$ East of the Greenwich Meridian. It is about $204 \mathrm{~km}$ east of Ibadan (Figure 2), capital of Oyo state; $168 \mathrm{~km}$ west of Benin City, capital of Edo state; $311 \mathrm{~km}$ north-east of Lagos; and $323 \mathrm{~km}$ south-west of Abuja, the Federal Capital Territory of Nigeria. Akure town spreads over an area of about $15,500 \mathrm{~km}^{2}$ in about $370 \mathrm{~m}$ above the sea level. Its population figure by the National
Population Census $\mathrm{NPC}^{21}$ was just 71,106. With the influx of public servants into the town consequent upon state creation in 1976, the population rose to 239,124 and 360,268 in 1991 and 2006 respectively $\mathrm{NPC}^{21}$ with a projection of 476,159 to year 2014 when this study was carried out (Figure 3), using the 3.18 annual growth rate.

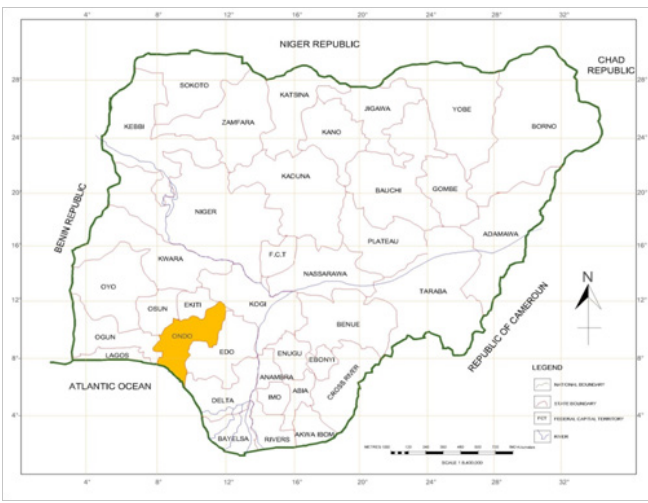

Figure I ONDO state in the national setting.

Source: Dept. of surveys, federal ministry of works, abuja (20l4).

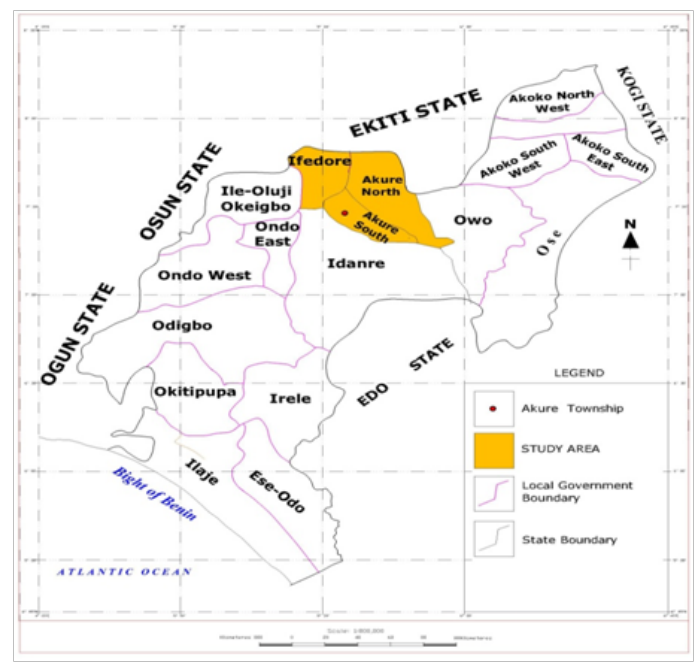

Figure 2 Ondo state and its eighteen local govt. areas.

Source: Ondo state ministry of lands and housing, akure (2014).

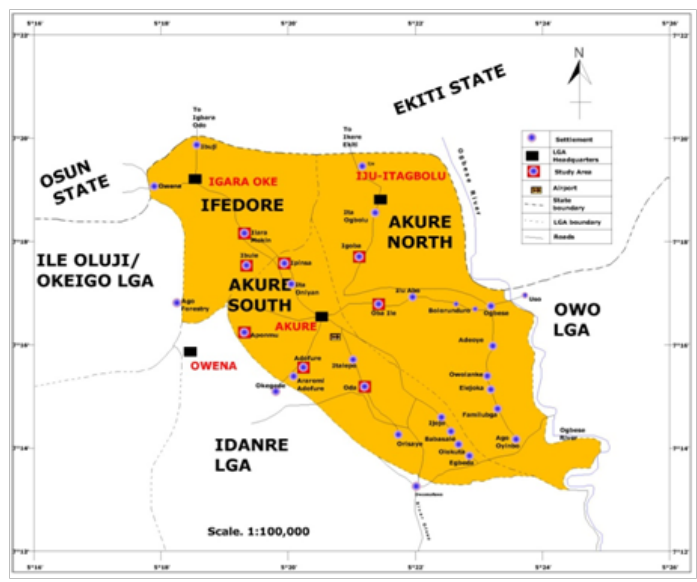

Figure 3 Locational map of the study area in regional setting.

Source: Ondo state ministry of lands and survey, akure (20I4). 


\section{The database}

Data collection for this study was essentially through Aerial Imagery Overlay (AIO) with the aid of RS and GIS techniques. Personal observations were also made on the level and direction of the expansion. Other sources of data collection include government ministries and establishments for historical milieu of the area as well as base maps and population data used for the study. The study area has a total projected population of 476,159 in 2014 with a total land expanse of 125,212 hectares. The main approach used in this study was mainly post-classification comparison analysis of satellite imageries of Akure obtained at different decadal variations. This helps to show the direction and extent of growth in the study area from one period to the other. The studying period span through three decades and is divided as follows: 1985-1994, 1995-2004 and 2005-2014. The land cover for the study area is classified into four categories, which include: the built-up area (involving residential, commercial, industrial, recreational and educational land uses); thick vegetation (forested land areas); light vegetation (cultivated land areas), and the water bodies (rivers, streams, rivulets, etc).

\section{Results and discussion}

\section{Analysis of land cover classifications and urban sprawl between I 985 and 2014}

As shown in (Figure 4A \& 4B); larger proportion $(80,796$ hectares) of the study area were covered with thick vegetation in 1986 which accounted for $64.53 \%$ of the land area while 37,977 hectares $(30.33 \%)$ were cultivated and covered with light vegetation. Only $5.1 \%$ were developed areas which are either residential, commercial, recreational, industrial or educational land uses, occupying just about 6384 hectares land area. Fifty-six (56) hectares $(0.04 \%)$ were covered by water. This situation expresses the low level of development as at 1986 with a small compact urban area.

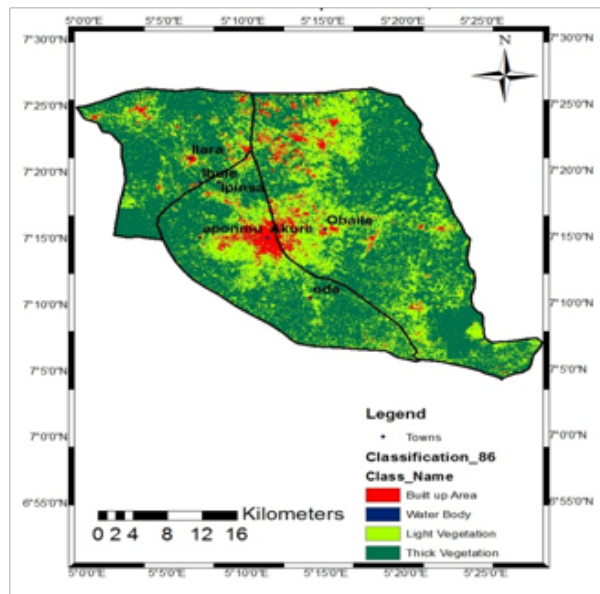

Figure 4A Land cover classification of akure as at 1986

In 2002, the percentage of built-up area had increased to $16.63 \%$ (20,885 hectares), cultivated area (light vegetation) also increased to 68,940 hectares $(55.06 \%)$ while the area covered by thick vegetation reduced drastically to 32,978 Hectares $(26.34 \%)$. This shows that much of the thick vegetation were cultivated (Figure 5A \& 5B) while some gave way to further development and urban expansion through building constructions and provision of public utilities. This is illustrated in Figures $5 \mathrm{a}$ and $5 \mathrm{~b}$.

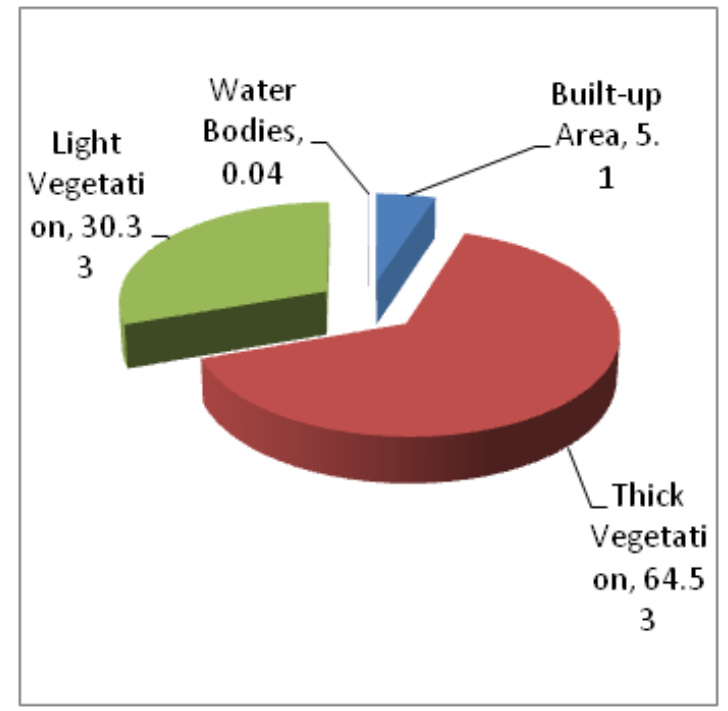

Figure 4B \% Land cover classification of akure for year 1986.

Source: Landsat 4 thematic mapper (TM) imagery (1986).

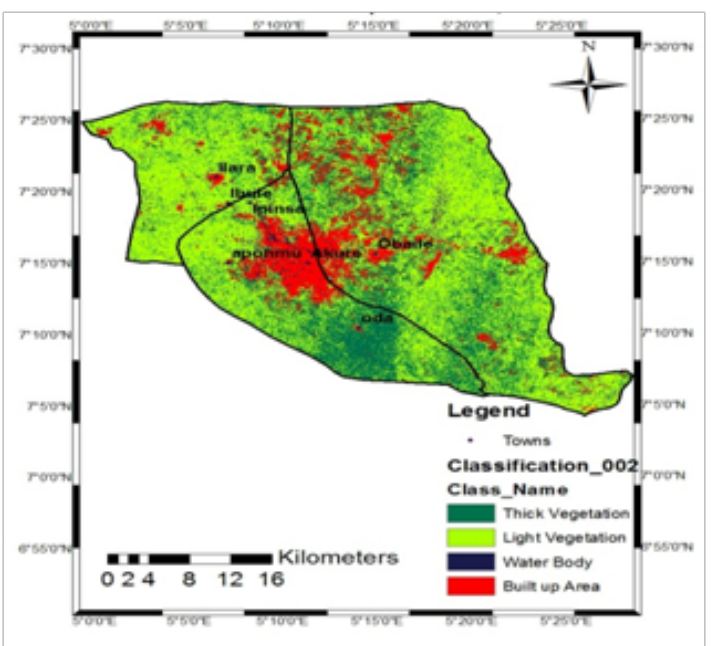

Figure 5A Land cover classification of akure as at 2002.

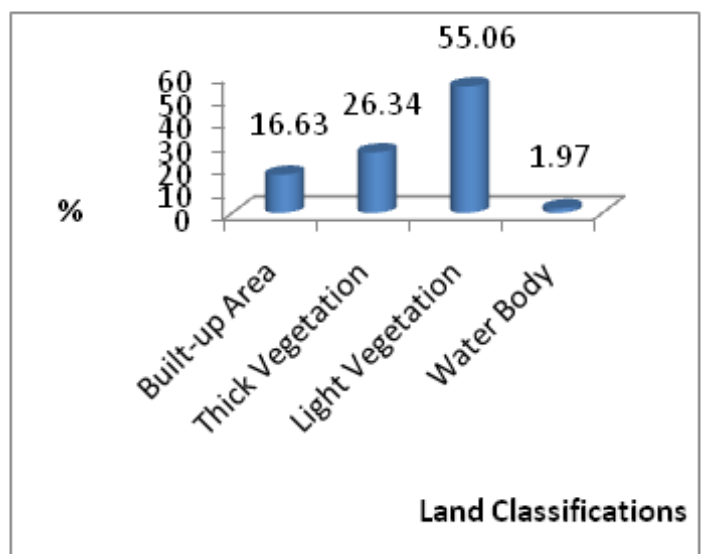

Figure 5B \% Land cover classification of akure for year 2002.

Source: Landsat 7 enhanced thematic mapper $\left(\mathrm{ETM}^{+}\right)$satellite imagery (2002)

The built-up area has further increased to about 22,985 hectares $(18.36 \%)$ in 2007 , light vegetation cover occupied 82,415 hectare 
$(65.82 \%)$ while areas covered by thick vegetation and water body reduced to 19,002 hectares $(15.18 \%)$ and 811 hectares $(0.64 \%)$ respectively (Figure 6A \& 6B). The land uses for the built-up area continue to increase till date while that of thick vegetation, light vegetation and area cover by water reduces.

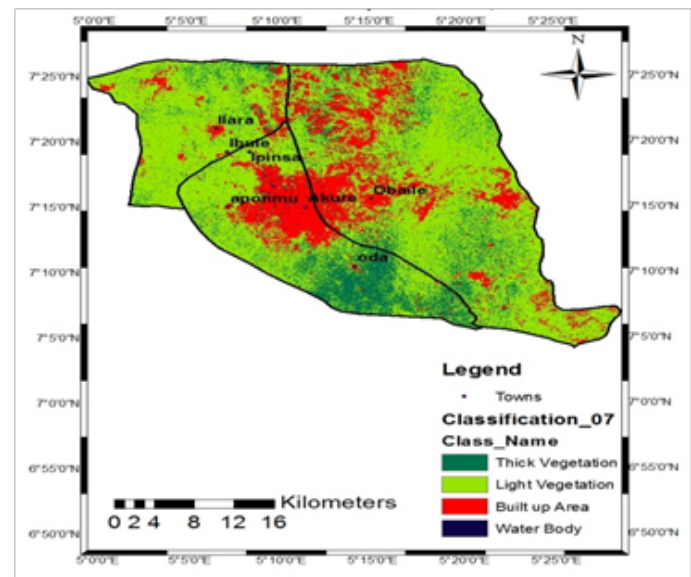

Figure 6A Land cover classification of akure as at 2007.

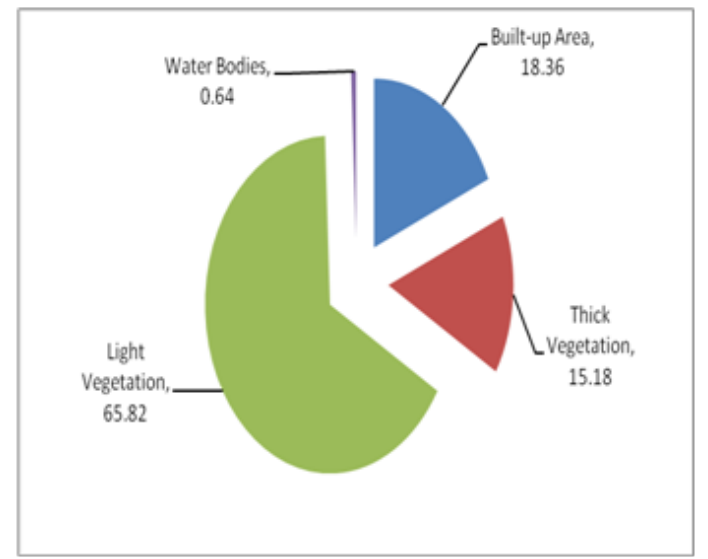

Figure 6B \% Land cover classification of akure for year 2007.

Source: Landsat 7 enhanced thematic mapper $\left(\right.$ ETM $\left.^{+}\right)$satellite imagery (2007)

In 2014 (Figure 7A \& 7B), land use for built-up area increased from 22,985 (in 2007) to 34,303 hectares $(27.40 \%)$ while light vegetation (the cultivated area) reduced from 82,415 hectares (in 2007) to 72,675 hectares in 2014. The reason for this might be because of drastic reduction in number of farmers since majority of people working on the farms had been taken over by civilization while some land areas meant for cultivation were acquired for provision of public utilities.

The inference deduced from this analysis is the rate of urban expansion as illustrated by the trend of increase in the built-up area and light vegetation (cultivated land areas). The drastic reduction in the percentage area covered by thick vegetation shows there was a phenomenal growth within the studying period. For instance, the built-up area increased by $22.3 \%$ between 1985 and 2014 as well as light vegetation (cultivated land areas) by $27.71 \%$. This is likely to be the result of much encroachment into the thick vegetation, rocky and undulating land areas for the purpose of building construction, quarry, blasting and mining activities. Besides, the economic situation in the state around the time (especially, the ealier years of the new millenium) was favourable for individuals, government and various establishments to engage in massive developments Oyinloye. ${ }^{9}$ For example, in 2002 (being the beginning of the millenium), various projects were consequently involved upon the discovery that the state falls within the mineral endowed region ODSBS, ${ }^{22}$ which accounted for the tremendous increase in the built-up areas, which result in massive physical expansion of the region. Again, Akure gained much influx of people seeking greener pastures being the state capital while the discovery of bitumen in the state attracted much investor and other immigrants within the studying period. Its administrative status and concentration of establishments like government ministries, several housing estates, Ondo State Oil Producing Area Development Commission (OSOPADEC) secretariat, Federal University of Technology, Akure (FUTA) and lot more were the centre of consideration for the attraction.

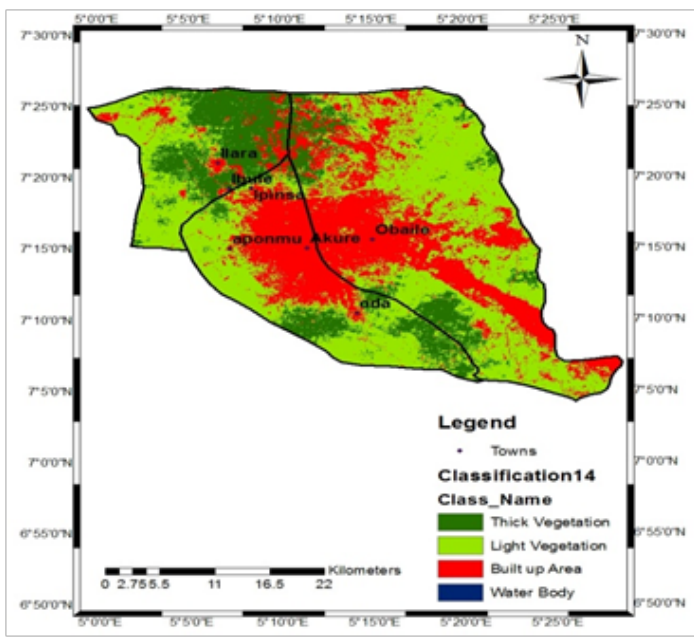

Figure 7A Land cover classification of akure as at 2014 .

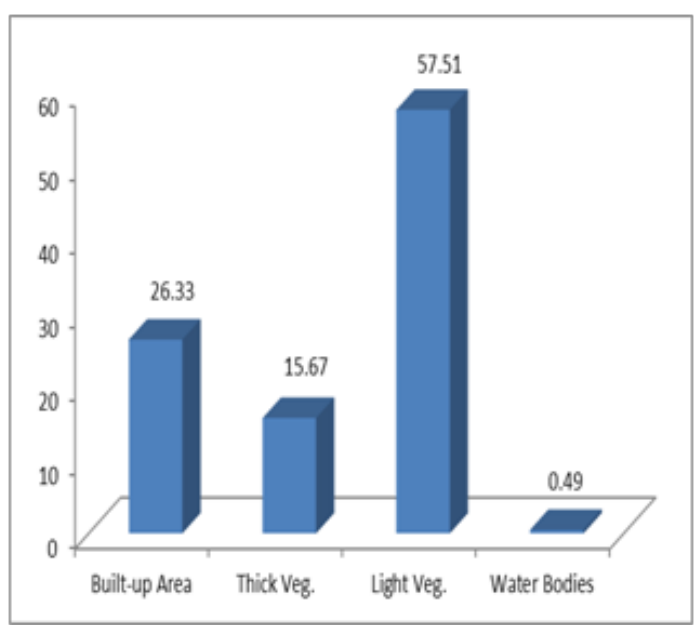

Figure 7B \% Land cover classification of akure for year 2014.

Source: Landsat operational land imager (oli) satellite imagery (2014).

\section{Land cover change (LCC) analysis for the year 1986, 2002, 2007 and 2014}

The LCC of Akure and the change detection analysis for the 19862002, 2002-2007 and 2007-2014 are presented in Table 1 \& Figure 8 . From the table and figure, the percentage increase of built-up area, light vegetation (cultivated land areas) and water body was higher between 1986 and 2002 than between 2002 and 2007. 
Table I Land Cover Change (LCC) Analysis for the year 1986, 2002, 2007 and 2014

\begin{tabular}{|c|c|c|c|c|c|c|}
\hline & $2002-1986$ & & 2007-2002 & & $2014-2007$ & \\
\hline The LULC & $\begin{array}{l}\text { Difference in } \\
\text { Area (Hecht) }\end{array}$ & $\begin{array}{l}\text { Difference in } \\
\text { Area (\%) }\end{array}$ & $\begin{array}{l}\text { Difference in } \\
\text { Area (Hecht) }\end{array}$ & $\begin{array}{l}\text { Difference in } \\
\text { Area (\%) }\end{array}$ & $\begin{array}{l}\text { Difference in } \\
\text { Area (Hecht) }\end{array}$ & $\begin{array}{l}\text { Difference in } \\
\text { Area (\%) }\end{array}$ \\
\hline Built-up Area & $|444|$ & 11.53 & 2160 & 1.73 & 11318 & 9.04 \\
\hline Thick Veg. & $-478 \mid 8$ & -38.19 & -13976 & -11.16 & -1379 & -1.11 \\
\hline Light Veg. & 30963 & 24.73 & 13475 & 10.76 & -9740 & -7.78 \\
\hline Water Body & 2413 & 1.93 & -1658 & -1.33 & -199 & -0.15 \\
\hline
\end{tabular}

Sources: Landsat Satellite Imageries (1986, 2002, 2007 and 20I4)

Table 2 Built-up Change Detection Analysis for Akure Urban Land cover (I 985 - 2034)

\begin{tabular}{llll}
\hline Year of growth & Growth area (ha.) & Cumulative area (ha.) & Percentage area \\
\hline 1986 & 6383.65 & 6383.65 & 5.1 \\
2002 & 20825.33 & 27208.98 & 16.63 \\
2007 & 22984.57 & 50193.55 & 18.36 \\
2014 & 32969.15 & 83162.7 & 26.33 \\
2034 Projected & 66881.02 & 150043.7 & 53.41 \\
\hline
\end{tabular}

Source:Author's Field Survey, 2014.

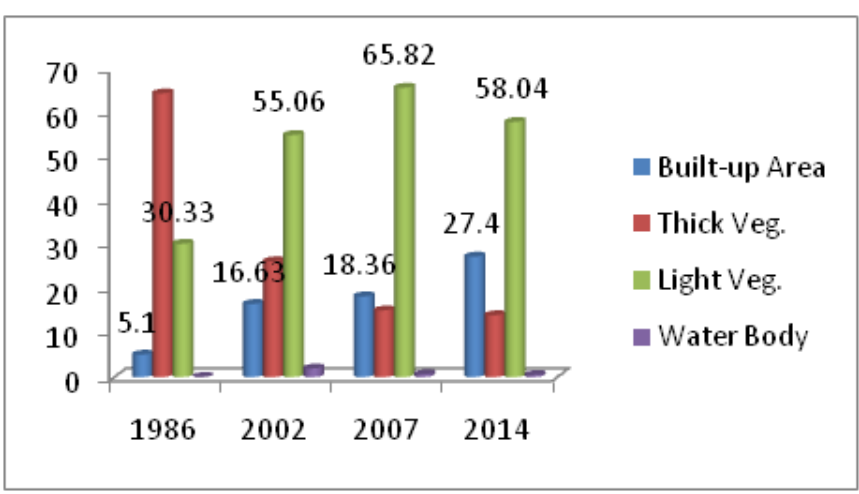

Figure 8 Land cover classification and change analysis in akure region.

Sources: Landsat satellite imageries (1986, 2002, 2007 and 2014).

Percentage difference for built-up area was much higher between 2007 and 2014 while other land classifications have negative index Thick vegetation was rapidly depleted and taken over by light vegetation and built-up land uses as indicated by the negative index throughout the studying period. This is an evidence of consistent growth and rapid development witnessed in the city.

\section{Urban built-up change analysis and predictive model for future expansion}

The spatial pattern of sprawling in Akure over a period of three decades (1985-2014), as shown in (Figures 4-7), express the direction and extent of growth in the period examined. For instance, between 1985 and 2002, the growth navigates towards the northern and the eastern parts of the region more than any other direction. These areas were earmarked for the construction of Government Residential Areas (GRAs) and most of government parastatals and ministries. Besides, the area was the location of Ijapo estate, a notable residential estate in the city which attracted much influx into the area. The construction of Ilesha-Akure-Owo express route which passes through the northeastern part of the city was another notable factor that play prominent role of attracting people to the area. But the direction of growth thereafter diffused to other directions, probabily due to congestion in this area and availability of cheap lands and good topography that favours construction in other parts of the city.

The location of Federal University of Technology, Akure (FUTA) in the north-western part of the city has much influence in attracting huge population of people into the area. Most staff of the institution and students preffer to live close to it, thereby makes the growth to be institutional attraction. Currently, the growth around this institution has almost captured Ipinsa and Ibule (the two nearest settlements) as high percentage of students of the institution find cheaper accommodation there as well as cheaper lands for staff and people from Akure to build houses and hostel accommodation for students. This and other important developments that parade the city revealed significant difference in stages of expansion and land uses within the studying periods. The findings corroborate the work of ${ }^{6,9}$ who observed significant difference in stages of development and growth in Akure since its inception as a state capital.

The use of GIS to predict future expansion of the study area and possible changes in land uses was modeled to guide policy makers in the management of land use activities in Akure and environs. Based on $3.6 \%$ growth rate adopted in ${ }^{9}$ for Akure, the predicting future expansion for the built-up area for a period of 20 years (2014 to 2034) is estimated at $68,793.41$ hectares. The pictorial representation is shown in (Figure 9). As seen in the figure; there is every possibility for Akure to become a full grown conurbation by 2034 when it would have subsumed many of its adjoining communities. 


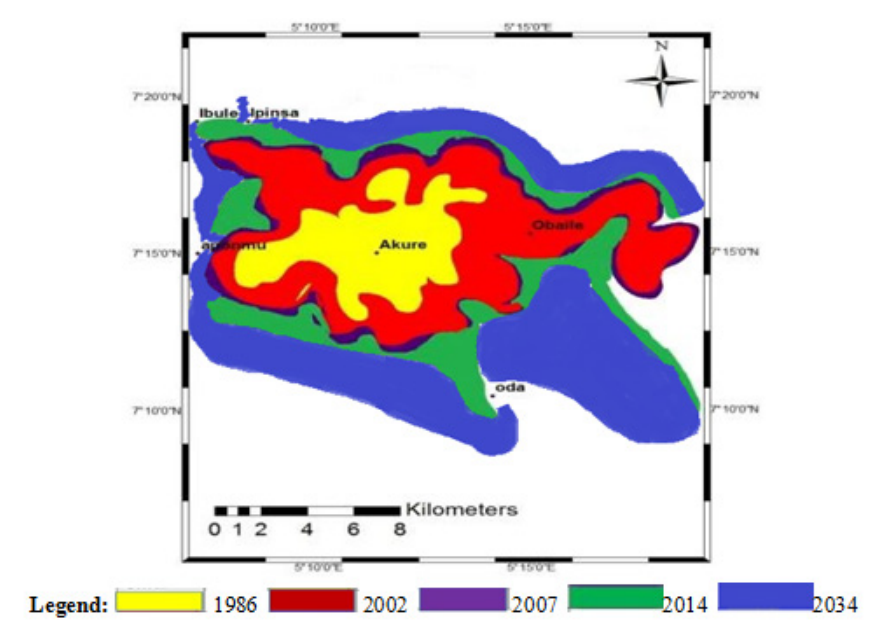

Figure 9 Built-up change detection analysis for akure urban land cover (19852034).

Source:Author's field survey, 2014.

\section{Conclusion}

The study gives a clear indication of unguided expansion in the growth of Akure which seriously affects the pattern of land uses in the city and its surrounding settlements. There were incompatible conversions of land uses and undue encroachment into green areas in the adjoining settlements due to favourable economic situation in the state around the period. In the early year of the millenium, Akure gained much influx of people being the state capital; and most importantly, due to the discovery of bitumen in the state which attracted much investors and other immigrants in quest of greener pastures and job opportunities. Its administrative status and concentration of establishments were the key indices for this attraction. With this, the thick vegetation was massively encroached which consequently gave way to further developments and expansion from the city into various surrounding communities. ${ }^{23}$ Also, the regional setting of Akure has naturally influenced the direction of the expansion. Findings revealed that the city spread out along the fairly flat areas of the northwestern part of the city which appear to be more favorable to human settlements. Thus, the expansion first tend towards this direction before it began to diffuse to other areas.

Based on the major findings in this study, it has become pertinent to advance some policy recommendations. In the first instance, the unguided nature of Akure urban development whose effects on land use pattern are well prominent in the study area needs adequate attention. The check on this should commence with land acquisition and allocation procedures for various uses so as to guide against incompatible land uses. It is therefore recommended that ministries in-charge of land management should employ resourceful control measures over private and public land uses through effective zoning strategy. In view of this, the Development Control Department (DCD) in the Ministry of Urban Development and Physical Planning should be reinforced with strong tools to carry out their duties, particularly in the area of effective monitoring for sustainable development.

The existing land use in the study area is more of residential, most of which are aged and dilapidated. In some parts of the city, especially at the urban core; most of the old buildings are being removed and changed over to new ones. In the course of changing some of these buildings, the usages are always at variance with compatibility standard. They constitute nuisance rather than complementing the planning and environmental standards. In this regard, it is recommended that adequate monitoring be made by DCD and other stakeholders in urban planning, right from plan approval stage to erection of structures so as to forestall such occurrences with a view to achieve a sustainable and virile livable environment. Besides, property rehabilitation strategy should be adopted on degraded landed properties rather than arbitrary removal and rambling replacements. This should involve improving the existing infrastructural facilities as well as providing new ones with a view to making their services functional and accessible to all and sundry. To reduce the level of encroachment into natural vegetation in the course of expansion, it is also suggested that vertical expansion should be encouraged in the form of story buildings, high scrappers, and the likes. It is believed that this will reduce the rate of land consumption and improve the structural quality as well as adding to the aesthetic value of the environment.

The administration of physical planning in Nigeria was not effective as far as promotion of orderly development of urban and rural communities is concern prior the enactment of Decree 88 of 1992 Nigerian Urban and Regional Planning Law (NURPL). Related programs on physical planning were carried out only on ad-hoc basis. However, the enactment of 1992 NURPL makes provision for improvement of urban area and city sustainability; essentially in part IV section 79-85 of the law. With this, it is expected that cities are to be in orderly shape and made sustainable for human living. But, in reality, this is not so. At local government level, planning is expected to be felt through various planning authorities since it is the closest tier of government to the people. But the authorities are almost become moribund since the mode of planning administration in Nigeria does not allow them to function. It is therefore recommended that the state of local government planning administration in Nigeria be reactivated and made functional.

The existing Master plan of Akure was produced in 1980 and has become inactive, old and superseded. There is need for a more comprehensive one as well as Regional Plan to guide the development and spatial growth of the region. These plans are to be administered by a constituted Board which is to be ENDOWED with responsibility to maintain orderly and aesthetic environment in the region. The board is to be made responsible for the preparation and implementation of planning schemes as well as local, area and structural plans in conformity with the state and regional plans. This will go a long way to assist in regulating land uses for sustainable development in the area.

\section{Acknowledgements}

None.

\section{Conflict of interest}

The author declares no conflict of interest.

\section{References}

1. Glaeser E, Kahn M. Sprawl and Urban Growth. In Handbook of Regional and Urban Economics. Amsterdam, Netherlands; 2004. p. 2481-2528.

2. Alonso W. Location and Land Use. England: Harvard University Press; 1964.

3. Mills ES. An Aggregate Model of Resource Allocation in a Metropolitan Area. American Economic Review. 1967;57:197-210. 
4. Muth R. Cities and Housing. USA: Chicago University Press; 1969.

5. Mirkatouli J, Hosseini A, Neshat A. Analysis of land use and land cover spatial pattern based on Markov chains modelling. City, Territory and Architecture. 2015;2(4):1-9.

6. Balogun IA, Adeyewa DZ, Balogun AA, et al. Analysis of Urban Expansion and Land Use Changes in Akure, Nigeria using RS and GIS techniques. Journal of Geography and Regional Planning. 2011;4(9):533-541.

7. Arnfield AJ. Two Decades of Urban Climate Research: A review of turbulence, exchange of energy and water, and the urban heat island in Inter. Journal of climatology. 2003;23:1-26.

8. Kufoniyi O. Towards 3D GIS for Efficient Management of Urban Environment. Proceeding of Technical Session of the $32^{\text {nd }}$ AGM and Conference of the Nigerian Institution of Surveyors, Nigeria; 1998. p. $5-7$.

9. Oyinloye MA. Spatial Analysis of Urban Growth in Akure. Nigeria: Federal University of Technology; 2010.

10. Olofin EA. The challenges of desertification and its effects on physical planning in Nigeria. A paper presented at the $43^{\text {rd }}$ Annual Conference of the Nigerian Institute of Town Planners held at Women Development Centre, Nigeria; 2012. p. 7-10.

11. Rimal B. Urbanization and the Decline of Agricultural Land in Pokhara Sub-metropolitan City. Nepal. Journal of Agricultural Science. 2013;5(1):54-65.

12. Oduwaye Leke. Urban Planning Implications of Changing Land Use Structure of Metropolitan Lagos, Nigeria. In: Schrenk M, editor Proceedings of Real Corp 2013 Tagungsband Planning Times, Italy; 2013. p. 20-23.

13. Oduwaye Leke. Urban Land Use Planning and Reconciliation. Inaugural Lecture Series 2015. Nigeria: University of Lagos; 2015.
14. Adesina FA, Siyanbola WO, Okelola FO, et al. Potential of Agro-forestry for climate change mitigation in Nigeria:Some preliminary estimates. Global Ecology Biogeography. 1999;8(2):163-173.

15. Fasal S. Urban expansion and loss of agricultural land-A GIS based study of Saharanpur city. India in Environmental Urbanization. 2000;12(2):133-149.

16. Zhao LM, Dickson RE, Tian YH. Evidence for a significant urbanization effect on urban climate in China. USA: P National Academic of Science; 2004. 101:9540-9544.

17. Owoeye JO. Urban Sprawl and Changing Land Use Pattern in Akure Region, Nigeria. Unpublished PhD Thesis submitted to the Department of Geography and Planning. Nigeria: Ekiti State University; 2016.

18. Hegazy IR, Kaloop MR. Monitoring Urban Growth and Land Use Change Detection with GIS and Remote Sensing Techniques in Daqahlia governorate Egypt. International Journal of Sustainable Built Environment. 2015;4(1):117-124.

19. Oyinloye MA. Geospatial Analysis of Urban Growth-The case of Akure, Nigeria. American Journal of Social Issues and Humanities. 2013;3(4):200-212.

20. Akinbode OM, Eludoyin AO, Fashae OA. Temperature and relative humidity distributions in a medium-size administrative town in Southwestern Nigeria. Journal of Environmental Management. 2007.

21. National Population Commission (NPC, 1991 and 2006). National Population Census Reports. 2006.

22. Ondo State Bureau of Statistics. Report of Integrated Household Survey in Ondo State 2011 (World Bank Project). Printed under the auspices of NSDP/SRF. 2012.

23. Tofowomo A. The Planning Implications of Urban Sprawl in Akure. $4^{\text {th }}$ ISOCARP Congress 2008. 2008. 